\title{
Corporate Sustainability Performance Assessment: CRITIC-ARAS Integrated Model
}

DOI: $10.26466 /$ opus.913777

\author{
$\underline{\text { Tuba Özkan * }}$ - Aliriza A $\breve{g}$ ** \\ * Asist. Prof. Dr., Atatürk University ,Erzurum/Turkey \\ E-Mail: tuba.ozkan@atauni.edu.tr \\ ORCID: 0000-0001-9510-2963 \\ ** Asist. Prof. Dr., Bayburt University, Bayburt/Turkey \\ E-Mail: alirizaag@bayburt.edu.tr \\ ORCID: $\underline{0000-0001-5345-6245}$
}

\begin{abstract}
In today's world, businesses struggle to survive in an intense competitive environment as a result of changes and developments that occur due to globalization. In this competitive environment, the importance of not only economic indicators but also social indicators is increasing day by day for businesses to gain competitive advantage. Therefore, businesses will be able to reveal their competitive advantage in their economic, social and environmental aspects in their sustainability reports. In this context, the main purpose of corporate sustainability and sustainability accounting is to meet the information needs of the business stakeholders and to measure and evaluate the corporate performances of the enterprises as a result of their activities for sustainability purposes. The aim of this study was to evaluate the corporate sustainability performance of the companies registered at Borsa Istanbul, operating in the production sector, as per various economic, environmental, and social indicators. An algorithm based on the integrated use of CRITIC and ARAS methods was used in the performance assessment of businesses, and corporate sustainability performance ranking results were presented. The CRITIC method, which is one of the objective weighting methods, was used to determine the weight of the criteria, while the ARAS method was used to determine the performance rankings of alternatives. As a result of the analysis in terms of corporate sustainability, OTKAR has been determined as the company with the best economic performance, AYGAZ with the best environmental performance, and KERVT with the best social performance.
\end{abstract}

Key Words: Corporate Sustainability, BIST, Manufacturing Sector, CRITIC, ARAS. Jel Classification $\quad$ : C6, L25, M14, Q56. 


\section{Kurumsal Sürdürülebilirlik Performans Değerlendirmesi: CRITIC-ARAS Bütünleşik Modeli}

\section{Öz}

Günümüz dünyasında işletmeler küreselleşmeye bağh olarak meydana gelen değişim ve gelişimler sonucu yoğun bir rekabet ortamında yaşam mücadelesi vermektedirler. Bu rekabet ortamında işletmelerin rekabet avantajı elde edebilmeleri için sadece ekonomik göstergelerin değil aynı zamanda sosyal göstergelerinde önemi gün geçtikçe artmaktadır. Dolayısıyla işletmeler sahip oldukları rekabet üstünlüklerini ekonomik, sosyal ve çevresel yönleriyle yayınlamış oldukları sürdürülebilirlik raporlarında ortaya koyabileceklerdir. Bu bağlamda kurumsal sürdürülebilirliğin ve sürdürülebilirlik muhasebesinin temel amacı işletme paydaşlarının bilgi ihtiyaçlarını karşılayarak işletmelerin sürdürülebilirlik amaçlarına yönelik gerçekleştirdikleri faaliyetleri sonucu ortaya çıkan kurumsal performanslarım ölçmek ve değerlendirmektir.Çalışmada; Borsa İstanbul imalat sektöründe faaliyet gösteren işletmelerin ekonomik, çeoresel ve sosyal göstergeler doğrultusunda kurumsal sürdürülebilirlik performansların değerlendirmek amaçlanmıştır. Iş̧letmelerin performans değerlendirmesinde CRITIC ve ARAS yöntemlerinin bütünleşik kullanımına dayalı bir algoritma kullanılmış ve kurumsal sürdürülebilirlik performans sıralama sonuçları ortaya konulmuştur. Objektif ă̆ırlıklandırma yöntemlerinden biri olan CRITIC yöntemi kriterlerin ağırlığını belirlemek için kullanılırken, ARAS yöntemi ise alternatiflerin performans sıralamaların belirlemek için kullanılmıştır. Yapılan analiz sonucunda kurumsal sürdürülebilirlik açısından; OTKAR en iyi ekonomik performansı, AYGAZ en iyi çevresel performansı ve KERVT en iyi sosyal performansı gösteren işletme olarak belirlenmiştir.

Anahtar Kelimeler: Kurumsal Sürdürülebilirlik, BIST, Imalat Sektörü, CRITIC, ARAS.

Jel Sinıflandirmasi: $\quad$ C6, L25, M14, Q56 


\section{Introduction}

In today's world, businesses that we can describe as the lifeblood of the economy, use scarce resources to meet human needs, allowing countries to develop and the welfare level of society to increase; while on the other hand, they struggle to survive in a relentless global competitive environment. Within this cycle, businesses have negative effects on humanity and the environment. Monitoring and controlling these negative effects have significantly increased the importance of sustainable development (Tüm, 2014, p.60). The concept of sustainable development, which gained importance in the 1970s, was officially raised on the international platform for the first time with the Brundtland report published in 1987 by the World Commission on Environment and Development. Sustainable development, with the main theme of combining economic and ecological considerations, is expressed as the search for ways to meet the needs and expectations of today's generation without compromising the needs and expectations of future generations. (Koçaslan, 2010, p.54). In brief, sustainable development is a long-term economic model that aims to use the scarce resources in nature effectively and efficiently, and on the other hand, takes into account the environmental quality and people, known as human resources. (Tiraş, 2012, p.60).

In order for businesses to gain a competitive advantage in a globally competitive environment, the importance of not only the economic indicators but also social indicators are increasing day by day. Therefore, businesses will be able to reveal their competitive advantage in their published sustainability reports, highlighting their economic, social, and environmental aspects. In this direction, sustainability indices and rating agencies associated with financial markets have emerged, which are aimed at both providing investors with information about the sustainability performance of businesses and identifying businesses that set an example in the field of sustainability. (Searchy and Elkhawas, 2012, p.79). The sustainability index, emerging in developed economies due to the ever-increasing importance of sustainability, was established in Borsa Istanbul (BIST) in 2014. (Önder, 2017, p.938).

In this study, the corporate sustainability performances of 6 companies trading in the BIST production sector, were evaluated using an integrated model consisting of CRITIC-ARAS methods. This study contributes to the lit- 
erature, since it is the first study in which the corporate sustainability performance was tried to be determined by using the CRITIC-ARAS integrated method. The operation of the study is as follows: After mentioning the concept of corporate sustainability in the introduction section, a literature review has been conducted by mentioning the relationship between sustainability accounting and sustainability reporting. Then, subsequent to mentioning the data used and methods implemented, the analysis and the findings were included. Finally, a general evaluation of the study, along with various recommendations, was presented.

\section{Corporate Sustainability}

Sustainability, where the importance is increasing day by day due to economic, social, and environmental reasons occurring in the world along with industrialization, is expressed as ensuring the continuity of natural resources in the world in a sustainable manner. (Gladwin et al., 1995, p.4). Accordingly, the corresponding form of sustainable development for businesses, expressed with sustainability, is expressed as corporate sustainability. (Saufi et al., 2016, p.375). Corporate sustainability emphasizes that although companies have responsibilities towards their stakeholders, businesses should consider financial and non-financial data when making decisions (Searchy and Elkhawas, 2012, p.79). In other words, corporate sustainability can be expressed as corporate policies and investment strategies that are implemented to meet the information needs of the current and future stakeholders of companies. In this direction, corporate sustainability performance helps to measure the extent to which businesses take into account the economic, social, and environmental factors in their activities, and their effects on society and business (Artiach et al., 2010, p.31-32). Therefore, businesses act in line with economic, environmental, and social purposes within the scope of corporate sustainability. Accordingly, corporate sustainability has three dimensions, including social, economic, and environmental dimensions. (Özdemir and Pamukçu, 2016, p.16). 


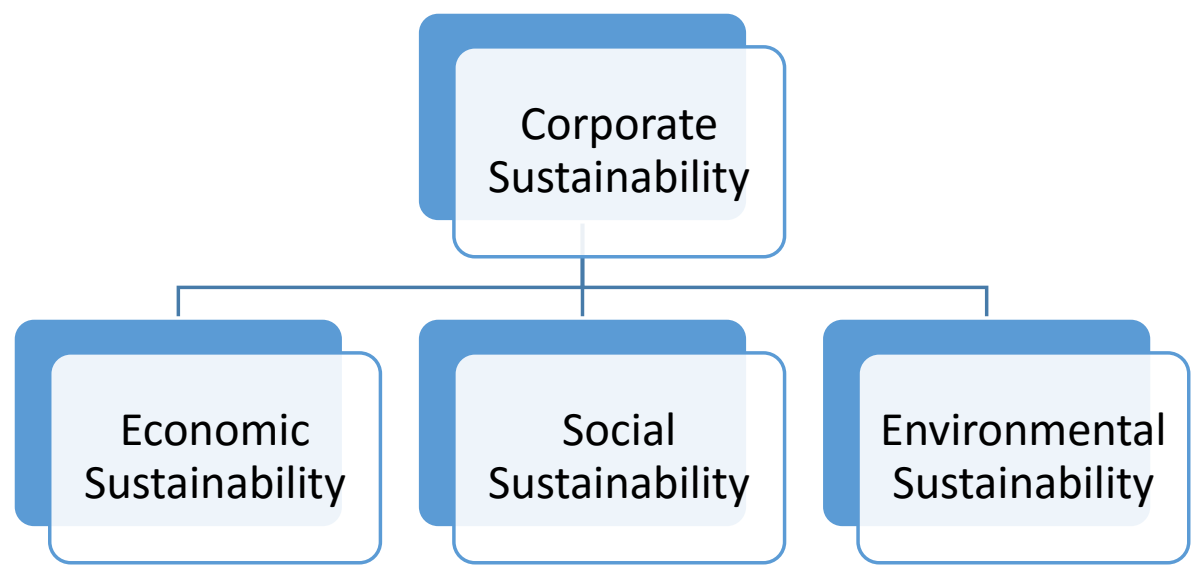

Figure 1. Dimensions of Corporate Sustainability

Corporate sustainability provides benefits to businesses in many ways. These include:

- It lowers the costs of the companies. It enables businesses to use environmentally friendly and innovative production techniques to reduce production costs, as well as to improve the working environment, and effectively manage the costs for occupational health and safety.

- It enables businesses to easily obtain the funds they need from the capital markets.

- It provides market advantages to businesses and enables businesses to gain a competitive advantage.

- It allows businesses to improve their corporate reputation in society.

- It allows investors who treasure social responsibility to invest in businesses.

- It enables businesses to have a say in the establishment of standards and legal regulations related to the sectors in which they operate.

- It ensures that institutional accountability and transparency are increased.

- It enables the establishment of an effective internal control system in businesses and increases the motivation of employees (Tokgöz and 
Önce, 2009, p.268,269, Yücel, 2016, p.175; Demircioğlu and Ever, 2019, p.65).

\section{Sustainability Accounting and Corporate Sustainability Reporting}

Sustainability accounting, with is a sub-branch of accounting, can be expressed as a set of systems that establish connections between environmental and socio-economic impacts, as well as ecological and social impacts of any economic system, along with issues related to the social, environmental and economic dimensions of sustainability; and which also records, analyzes, and reports the items related to these connections. (Schaltegger and Burritt, 2010, p.377). Therefore, sustainability accounting examines the activities of businesses and the impact of these activities on corporate sustainability, taking into account the economic, social, and environmental factors arising as a result of the activities of the businesses. (Fülöp and Hernádi, 2013, p.333). Accordingly, the main purpose of sustainability accounting is to assess the corporate performance of businesses that results from their activities towards their sustainability target (Lamberton, 2005, p.18; Demircioğlu and Ever, 2019, p.65).

In the globalizing world, businesses are assessed not only in terms of their economic aspects, but also in terms of their social and environmental aspects. Sustainability reports, which are important in this context, ensure that businesses behave responsibly towards the environment in which they operate, and that they not only increase transparency and accountability, but also provide the information needed by the decision-makers (Tuan, 2019, p.234; Demircioğlu and Ever, 2019, p.62). So, the financial and non-financial data required for businesses to create sustainable strategies in line with corporate sustainability can be obtained from the sustainability accounting system (Tüm, 2014, p.68).

\section{Literature}

When the literature is examined, there are many studies examining the relationship between corporate sustainability and the performance of businesses, and the impact of corporate sustainability on business profitability. These include: 
Lo and Sheu (2007), in their study, examined the impact of corporate sustainability on the value of companies. The data set of this study consists of the economic, social, and environmental data of 349 non-financial US businesses listed in the SandP 500 index between 1999 and 2002. As a result of the study, it was determined that there was a positive relationship between corporate sustainability and the value that the business is worth. On the other hand, it was found that businesses that take economic, social, and environmental factors into account in their investment strategies gained an advantage in the market, and that there was a strong relationship between corporate sustainability and sales, which was responsible for the increase in the value of the business.

In their study, Collison et al. (2008) examined the relationship between the factors such as environmental sustainability, investor relations, respect for human rights, supply chain standards, fight against corruption, and the financial performance between 1996 and 2005 of businesses in the FTSE4GOOD (Emerging markets index) in different countries within the framework of social responsibility. As a result of the study, it was found that the businesses in the FTSE4GOOD index achieved more returns by taking a high risk, which had a positive effect on their financial performance.

Reddy and Gordon, in their study (2010), examined the impact of sustainability reporting on the financial performance of businesses. The scope of the study consists of 68 businesses, 17 of which are listed on the New Zealand Stock Exchange, and 51 on the Australian Stock Exchange. As a result of the study, it was determined that the sector of operation, sustainability reporting, and environmental factors have impacts on financial performance. However, it was determined that there was a statistically positive relationship between sustainability reporting and market return of companies listed on the Australian Stock Exchange, but not with companies listed on the New Zealand Stock Exchange.

Aggarwal (2013), in his study, examined the effect of sustainability degrees of businesses on financial performance by using various profitability ratios of businesses operating in India. In addition, within the framework of sustainability, the effects of society, employees, environment, and management factors on financial performance were examined. As a result of the 
study, it was found that there was no relationship between the degree of sustainability and financial performance, and that the sustainability performance had a positive impact on the employees, the environment, and management.

In his study, Fettahoğlu (2013) examined the relationship between the social responsibilities of businesses and their financial performance. The scope of the study consisted of 16 businesses that are listed on BIST and which have published their sustainability reports between 2009-2011. In the study, data was comprised of various ratios as components of social responsibility that encompassed relationships with employees, society, and the environment, and product responsibility factors. In the results of the analysis, significant relationships were determined between some of the ratios and the components of social responsibility, while it was observed that some of them had no relationship with each other.

In their study, Marti et al. (2015) examined the effects of corporate social responsibility strategies on financial performance in the short and long term. In the study, various data of businesses included in the Stoxx Europe 600 Index and the Stoxx Europe Sustainability Index between 2007-2010 were used. According to the results of the analysis, it was found that the development level of the country's economy and the size of the business affects the financial performance in the businesses that follow a corporate social responsibility strategy.

Çitak and Ersoy (2016), in their study, examined the response of investors to businesses included in the BIST Sustainability Index, based on the return on equity, and market to book ratio. As a result of various analyzes conducted, it was found that the market to book ratio of the companies included in the sustainability index was higher than that of companies not included in this index, and that there was no significant difference observed between the rates of return of businesses that were included in the sustainability index as well as those that were not included.

In his study, Önder (2017) examined whether the inclusion of businesses in the BIST 100 index in the Sustainability Index has an impact on their profitability. In this direction, he analyzed the various data from 2016 of 91 businesses included in the BIST 100 index with the multiple linear regression method. According to the results of the analysis, it was determined whether the inclusion of the company in the Sustainability Index had any impact on the profitability of the company. 
In their study, Wiengarten et al. (2017) examined the impact of the personal characteristics of people appointed as corporate sustainability managers on financial performance. In the study, the profitability ratios of 123 businesses were analyzed by multiple regression method with various variables, covering the years 2004-2012. As a result of the analysis, it was found that managers who were involved in corporate sustainability have a positive impact on the profitability of the business; and especially, it was observed that female managers who were competent in the area of corporate sustainability had a positive impact on financial performance.

Sak and Dalgar (2020), in their study, examined the effects of corporate sustainability practices on financial performance. In the study conducted, various financial data of 35 businesses in the BIST Sustainability Index were analyzed using the panel data analysis method. According to the results of the analysis, it was found that corporate sustainability practices have a positive effect on the financial performance of businesses.

\section{Data and Method}

6 companies that are listed on the BIST manufacturing sector that published a sustainability report, and which we considered for common criteria, were included within the scope of the study. 2019 corporate sustainability performances of these 6 companies were evaluated with a CRITIC-based ARAS integrated model. In the study, initially, the indicators of the businesses regarding their economic, environmental, and social aspects were considered as decision criteria. A total of 18 criteria were determined as indicator criteria, including 7 as economic indicator criteria, 6 as environmental indicator criteria, and 5 as social indicator criteria. Then, the importance weights of these criteria were obtained by using the CRITIC method, which is one of the weighted objectives methods. Corporate sustainability performances of the businesses were determined by including the determined importance weights in the ARAS method. Microsoft Excel software was used for the analysis made with CRITIC and ARAS methods. The environmental and social indicator criterion data used in the study were obtained from 2019 sustainability reports published by the businesses on their own websites. On the other hand, the economic indicator criterion data were prepared using 2019 financial reports 
published on the Public Disclosure Platform (PDP). The companies and stock exchange codes included in the study are shown in Table 1.

Table 1. Companies Included in the Analysis

\begin{tabular}{ll}
\hline BIST Code & Company Name \\
\hline AKSA & Aksa Acrylic \\
AEFES & Anadolu Efes \\
AYGAZ & Aygaz \\
FROTO & Ford Automotive \\
KERVT & Kerevitaş Food \\
OTKAR & Otokar Automotive \\
\hline
\end{tabular}

Corporate sustainability performance indicators that were selected for the analysis of the businesses are listed in Table 1 , and the information regarding these indicators are given in Table 2.

Table 2. Indicator Criteria Used in Analysis, Their Orientations, and Exchange Codes

\begin{tabular}{ll}
\hline Economic Indicators & Current Ratio \\
& Rate of Increase in Net Sales \\
& Return on Equity Ratio \\
& Return on Assets Ratio \\
& Earnings Per Share \\
& Equity Ratio \\
& Rate of Increase in Cost of Sales \\
\hline Environmental Indicators & Greenhouse Gas Emissions (ton $\left.\mathrm{CO}_{2}\right)$ \\
& Total Energy Consumption (GJ) \\
& Non-Hazardous Waste Amount (ton) \\
& Hazardous Waste Amount (ton) \\
& Water Consumption (m $\left.{ }^{3}\right)$ \\
& Wastewater Amount (m³) \\
\hline Social Indicators & Total Number of Employees \\
& Number of Employees Who Left the Job During the Year \\
& Number of Newly Recruited Employees During the Year \\
& Training Hours Per Employee \\
& Accident Frequency Rate \\
\hline
\end{tabular}

\section{CRITIC Method}

CRITIC (CRiteria Importance Through Intercriteria Correlation) technique is an objective weighting method introduced into the literature by Diakoulaki et al. (1995). It is a method that proposes the calculation of weights by taking the correlation between criteria into consideration. Criterion weights are created based on contrast density and conflict between the criteria (Diakoulaki 
et al., 1995:764). In this method, objective weighting is performed by considering the correlation between criteria and the standard deviations of the criteria (Akçakanat, Aksoy and Teker, 2018:5). The method includes an implementation process consisting of five steps. (Diakoulaki, 1995, p.764-765; Kirac1 and Bakır, 2018, p.160-161; Akbulut, 2019, p.253-254):

1. Step: Creating the Decision Matrix

2. Step: Normalizing the Decision Matrix

3. Step: Creating the Matrix for Correlation Coefficients

4. Step: Obtaining $c_{j}$ Information Quantity

5. Step: Determination of Weight Values of the Criteria

\section{ARAS Method}

ARAS (Additive Ratio ASsessment) method was introduced to the literature as an option for a new approach for the solution of MCDM problems in a study conducted by Zavadskas and Turskis in 2010. In this method, the utility function values of the decision criteria are compared with the utility function value of the alternative in the optimal state. The most important feature of the ARAS method, which makes it different from other MCDM methods, is that it provides objective results in proportional rating. For example, if the highest score is calculated to be 8 under the assumption that the optimal value of a criterion is 10 , the optimal value of the criterion is considered as 0.8 and not 1.0 , as compared to other MCDM methods. Thus, the objectivity is maintained in this method. (Ayçin, 2020, p.52).

The analysis steps of the Aras method are as explained below (Zavadskas and Turskis, 2010, p.163-165; Dahooie et al., 2018, p.11-13; Balezentiene and Kusta, 2012, p.4; Ayçin, 2020, p.52-55).

Step 1. Creating the Decision Matrix: In the first step of the ARAS method, a decision matrix consisting of $(\mathrm{m})$ alternatives and $(\mathrm{n})$ criteria is prepared with the help of equation (1) in a similar manner to other MCDM methods. However, unlike other MCDM methods, there is a row of optimal values for each criterion in the initial decision matrix in the ARAS method. 


$$
\left[\begin{array}{cccc}
x_{01} & x_{02} & \ldots & x_{0 n} \\
x_{11} & x_{12} & \ldots & x_{1 n} \\
\vdots & \vdots & \ldots & \vdots \\
x_{m 1} & x_{m 2} & \ldots & x_{m n}
\end{array}\right] \quad i=0,1, \ldots, m ; \quad j=1,2, \ldots, n
$$

If the optimal value for a criterion in the decision problem is not known, this optimal value is calculated using equation (2) if the criterion is utilityoriented, and equation (3) if it is cost-oriented.

$$
\begin{aligned}
& x_{0 j}=\operatorname{maks}_{i} x_{i j} \\
& x_{0 j}=\min _{i} x_{i j}
\end{aligned}
$$

Step 2. Creating a Normalized Decision Matrix: The values for the criteria taken into consideration in decision problems can be in different scales or in different units. Therefore, at this stage, the values related to the criteria with different units should be standardized by the normalization process, so that they take values in the range of $[0,1]$. While the normalization process is performed, equation (4) is used for utility-oriented criteria, and equation (5) is used for cost-oriented criteria.

$$
\begin{aligned}
& \bar{x}_{i j}=\frac{x_{i j}}{\sum_{i=0}^{m} x_{i j}} \\
& \bar{x}_{i j}=\frac{1 / x_{i j}}{\sum_{i=0}^{m} x_{i j}}
\end{aligned}
$$

The normalized decision matrix consisting of the values obtained after using equations (4) and (5) is shown by equation (6).

$$
\bar{X}=\left[\begin{array}{cccc}
\bar{x}_{01} & \bar{x}_{02} & \ldots & \bar{x}_{0 n} \\
\bar{x}_{11} & \bar{x}_{12} & \ldots & \bar{x}_{1 n} \\
\vdots & \vdots & \ldots & \vdots \\
\bar{x}_{m 1} & \bar{x}_{m 2} & \ldots & \bar{x}_{m n}
\end{array}\right] \quad i=0,1, \ldots, m ; \quad j=1,2, \ldots, n
$$


Step 3. Creating a Weighted Normalized Decision Matrix: At this stage, the decision matrix normalized in the previous stage, is weighted by considering the criterion weights $\left(\mathrm{w}_{\mathrm{j}}\right)$. wj values should take values between 0 and 1 , and the sum of the criterion weights should be 1 , as shown by equation (7).

$$
\sum_{j=1}^{n} w_{j}=1
$$

After the criteria weights are determined, the values for the weighted normalized decision matrix should be obtained by multiplying the values in the normalized decision matrix by the criteria weights. This process is performed by making use of Equation (8).

$$
\hat{x}_{i j}=\bar{x}_{i j} \cdot w_{j}
$$

Using the values of the weighted normalized decision matrix calculated with the help of Equation (8), the weighted normalized decision matrix is obtained as shown by equation (9).

$$
\hat{X}=\left[\begin{array}{cccc}
\hat{x}_{01} & \hat{x}_{02} & \ldots & \hat{x}_{0 n} \\
\hat{x}_{11} & \hat{x}_{12} & \ldots & \hat{x}_{1 n} \\
\vdots & \vdots & \ldots & \vdots \\
\hat{x}_{m 1} & \hat{x}_{m 2} & \ldots & \hat{x}_{m n}
\end{array}\right] \quad i=0,1, \ldots, m ; \quad j=1,2, \ldots, n
$$

Step 4. Calculation of the Optimality Function: Taking into account the weighted normalized decision matrix shown in Equation (9), optimality function values are calculated for each decision alternative with the help of equation (10).

$$
S_{i}=\sum_{j=1}^{n} \hat{x}_{i j} \quad i=0,1, \ldots, m ; \quad j=1,2, \ldots, n
$$

$S_{i}$ in Equation (10) is the optimality function of the decision alternative i. It is seen that the higher the $S_{i}$ value of a decision alternative, the better that decision alternative becomes. This is due to the fact that when considering the calculation process, $S_{i}$ is directly related to $x_{i j}$ and $w_{j}$ values that affect the final result. For this reason, the decision alternative with the highest optimality function value $\left(\mathrm{S}_{\mathrm{i}}\right)$ is a more effective alternative. 
Step 5. Calculation of Degree of Utility and Final Ranking: In the last step of the method, the final ranking will be obtained by calculating the degree of utility $\left(\mathrm{K}_{\mathrm{i}}\right)$. The degree of utility is found by proportioning the value of the optimality function of a decision alternative to the value of the optimality function of the best alternative. The degree of utility is calculated with the help of equation (11).

$$
K_{i}=\frac{S_{i}}{S_{0}} \quad i=0,1, \ldots, m
$$

The relative efficiency of the utility function values of the alternatives is

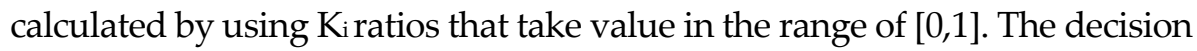
alternatives will be evaluated by sorting the calculated values in descending order.

\section{Findings}

In this section, findings obtained by using both CRITIC and ARAS methods and evaluations regarding these findings will be included. The stages of the methods have been shown for the economic performance dimension of 2019 as an example, and the environmental and social dimension performance results have been compared and evaluated.

\section{Determination of Criteria Weights with CRITIC Method}

The decision matrix created for 2019 data of BIST manufacturing businesses included in the scope of the study is presented in Table 3. The rows of the decision matrix created according to the CRITIC method contain the companies with the advantaged listed, while the columns of the matrix contain criteria. Since there are 6 businesses and 7 economic performance criteria in the application, a decision matrix of $6 \times 7$ has been prepared. The criterion with code E7, which is one of the criterion properties, has been created in a way that will affect the economic indicator performance at a minimum level, while other criteria have been created in a way that will affect it at the maximum level. 
Table 3. Decision Matrix

\begin{tabular}{llllllll}
\hline & Max & Max & Max & Max & Max & Max & $\begin{array}{l}\text { Min } \\
\text { E5 }\end{array}$ \\
& E1 & E2 & E3 & E4 & E6 & E7 \\
\hline AKSA & 1,05 & 3,06 & 18,62 & 6,63 & 0,86 & 36,66 & 3,76 \\
AEFES & 1,33 & 24,74 & 8,46 & 2,39 & 1,73 & 28,22 & 21,53 \\
AYGAZ & 1,06 & 6,87 & 10,98 & 5,49 & 0,91 & 50,01 & 3,74 \\
FROTO & 1,17 & 17,77 & 45,79 & 13,24 & 5,58 & 28,43 & 17,97 \\
KERVT & 2,47 & 2,92 & 20,32 & 4,84 & 0,21 & 27,77 & 1,09 \\
OTKAR & 1,87 & 44,8 & 68,45 & 14,12 & 14,65 & 23,81 & 39,23 \\
\hline
\end{tabular}

In the second step, the decision matrix created in the first step is normalized. The normalized decision matrix is presented in Table 4.

Table 4. Normalizing the Decision Matrix

\begin{tabular}{|c|c|c|c|c|c|c|c|}
\hline & $\begin{array}{l}\text { Max } \\
\text { E1 }\end{array}$ & $\begin{array}{l}\text { Max } \\
\text { E2 }\end{array}$ & $\begin{array}{l}\text { Max } \\
\text { E3 }\end{array}$ & $\begin{array}{l}\text { Max } \\
\text { E4 }\end{array}$ & $\begin{array}{l}\text { Max } \\
\text { E5 }\end{array}$ & $\begin{array}{l}\text { Max } \\
\text { E6 }\end{array}$ & $\begin{array}{l}\text { Min } \\
\text { E7 }\end{array}$ \\
\hline AKSA & 0,00 & 0,00 & 0,17 & 0,36 & 0,05 & 0,49 & 0,93 \\
\hline AEFES & 0,19 & 0,52 & 0,00 & 0,00 & 0,11 & 0,17 & 0,46 \\
\hline AYGAZ & 0,01 & 0,09 & 0,04 & 0,26 & 0,05 & 1,00 & 0,93 \\
\hline FROTO & 0,09 & 0,35 & 0,62 & 0,92 & 0,37 & 0,18 & 0,56 \\
\hline KERVT & 1,00 & 0,00 & 0,20 & 0,21 & 0,00 & 0,15 & 1,00 \\
\hline OTKAR & 0,58 & 1,00 & 1,00 & 1,00 & 1,00 & 0,00 & 0,00 \\
\hline
\end{tabular}

In this step, correlation coefficients are calculated and presented in Table 5 to determine the degree of relationship between criteria.

Table 5. Correlation Coefficients Between Criteria

\begin{tabular}{llllllll}
\hline & E1 & E2 & E3 & E4 & E5 & E6 & E7 \\
\hline E1 & 1,00 & 0,12 & 0,25 & 0,01 & 0,18 & $-0,56$ & $-0,08$ \\
E2 & 0,12 & 1,00 & 0,73 & 0,56 & 0,90 & $-0,57$ & $-0,99$ \\
E3 & 0,25 & 0,73 & 1,00 & 0,94 & 0,94 & $-0,57$ & $-0,76$ \\
E4 & 0,01 & 0,56 & 0,94 & 1,00 & 0,83 & $-0,37$ & $-0,61$ \\
E5 & 0,18 & 0,90 & 0,94 & 0,83 & 1,00 & $-0,52$ & $-0,90$ \\
E6 & $-0,56$ & $-0,57$ & $-0,57$ & $-0,37$ & $-0,52$ & 1,00 & 0,61 \\
E7 & $-0,08$ & $-0,99$ & $-0,76$ & $-0,61$ & $-0,90$ & 0,61 & 1,00 \\
\hline
\end{tabular}

In the fourth step, the total amount of information contained in each criterion was calculated by taking into account the correlation coefficients and standard deviations, and the values obtained are shown in Table 6.

Table 6. $C_{j}$ Values

\begin{tabular}{llllllll}
\hline $\mathrm{C}_{\mathrm{i}}$ & 2,4258 & 2,0432 & 1,7497 & 1,8880 & 1,7629 & 2,9150 & 3,3718 \\
\hline
\end{tabular}

In the last step, the criteria weights in Table 7 were calculated. The criterion with the highest weight is considered to be the most important criterion. 
Table 7. Importance Weights of the Criteria for 2019 Economic Dimension Indicators

\begin{tabular}{llllllll}
\hline $\mathbf{W}_{\mathrm{j}}$ & 0,1501 & 0,1265 & 0,1083 & 0,1169 & 0,1091 & 0,1804 & 0,2087 \\
\hline
\end{tabular}

As seen in Table 7, E7 (Rate of Increase in Cost of Sales), which is one of the indicators of the economic dimension in 2019, has been the criterion with the highest weight, with a value of 0.2087. On the other hand, E3 (Return on Equity Ratio) criterion has been the criterion with the lowest weight of 0.1083 .

Table 8. Importance Weights of the Criteria for 2019 Environmental Dimension Indicators

\begin{tabular}{lllllll}
\hline $\mathbf{W}_{\mathrm{j}}$ & 0,1179 & 0,1255 & 0,2333 & 0,2282 & 0,1482 & 0,1469 \\
\hline
\end{tabular}

The criterion, which has the highest weight among the environmental dimension indicator criteria for the year 2019 is C3 (Non-Hazardous Waste Amount) with a value of 0.2333 , as seen in Table 8 . On the other hand, the criterion with the lowest weight is $\mathrm{C} 1$ (Greenhouse Gas Emissions), with a value of 0.1179 .

Table 9. Importance Weights of the Criteria for 2019 Social Dimension Indicators

\begin{tabular}{llllll}
\hline $\mathbf{W}_{\mathbf{j}}$ & 0,1819 & 0,1979 & 0,1975 & 0,2035 & 0,2192 \\
\hline
\end{tabular}

The criterion, which has the highest weight among the social dimension indicator criteria for the year 2019, is S5 (Accident Frequency Rate) with a value of 0.2192 , as seen in Table 9. On the other hand, the criterion with the lowest weight is S1 (Total Number of Employees) with 0.1819 .

\section{Application of ARAS Method}

In this section, the weight coefficients of the criteria will be included in the ARAS method, and the corporate sustainability performance of the BIST manufacturing sector companies will be analyzed. The decision matrix in Table 10 is the first step of the ARAS method and shows the economic dimension criteria, the orientations of the criteria, and their optimal values. 
Table 10. Decision Matrix

\begin{tabular}{llllllll}
\hline & E1 & E2 & E3 & E4 & E5 & E6 & E7 \\
& Max & Max & Max & Max & Max & Max & Min \\
\hline AKSA & 1,05 & 3,06 & 18,62 & 6,63 & 0,86 & 36,66 & 3,76 \\
AEFES & 1,33 & 24,74 & 8,46 & 2,39 & 1,73 & 28,22 & 21,53 \\
AYGAZ & 1,06 & 6,87 & 10,98 & 5,49 & 0,91 & 50,01 & 3,74 \\
FROTO & 1,17 & 17,77 & 45,79 & 13,24 & 5,58 & 28,43 & 17,97 \\
KERVT & 2,47 & 2,92 & 20,32 & 4,84 & 0,21 & 27,77 & 1,09 \\
OTKAR & 1,87 & 44,8 & 68,45 & 14,12 & 14,65 & 23,81 & 39,23 \\
Optimal Value & 2,47 & 44,8 & 68,45 & 14,12 & 14,65 & 50,01 & 1,09 \\
\hline
\end{tabular}

In this step, the normalized decision matrix shown in Table 11 was obtained by using equation (4) for maximization (utility) oriented criteria and equation (5) for minimization (cost) oriented criteria.

Table 11. Normalized Decision Matrix

\begin{tabular}{llllllll}
\hline & E1 & E2 & E3 & E4 & E5 & E6 & E7 \\
& Max & Max & Max & Max & Max & Max & Min \\
\hline AKSA & 0,0921 & 0,0211 & 0,0772 & 0,1090 & 0,0223 & 0,1497 & 0,1066 \\
AEFES & 0,1160 & 0,1707 & 0,0351 & 0,0393 & 0,0448 & 0,1152 & 0,0186 \\
AYGAZ & 0,0930 & 0,0474 & 0,0455 & 0,0903 & 0,0236 & 0,2042 & 0,1071 \\
FROTO & 0,1028 & 0,1226 & 0,1899 & 0,2177 & 0,1446 & 0,1161 & 0,0223 \\
KERVT & 0,2162 & 0,0201 & 0,0843 & 0,0796 & 0,0054 & 0,1134 & 0,3676 \\
OTKAR & 0,1637 & 0,3090 & 0,2839 & 0,2321 & 0,3796 & 0,0972 & 0,0102 \\
Optimal Value & 0,2162 & 0,3090 & 0,2839 & 0,2321 & 0,3796 & 0,2042 & 0,3676 \\
\hline
\end{tabular}

After obtaining the normalized decision matrix, criterion importance weights calculated with the CRITIC method are integrated into the method at this stage. The weighted normalized decision matrix obtained with the help of equation (8) is shown in Table 12.

Table 12. Weighted Normalized Decision Matrix

\begin{tabular}{llllllll}
\hline & E1 & E2 & E3 & E4 & E5 & E6 & E7 \\
& Max & Max & Max & Max & Max & Max & Min \\
\hline AKSA & 0,0138 & 0,0027 & 0,0084 & 0,0127 & 0,0024 & 0,0270 & 0,0222 \\
AEFES & 0,0174 & 0,0216 & 0,0038 & 0,0046 & 0,0049 & 0,0208 & 0,0039 \\
AYGAZ & 0,0140 & 0,0060 & 0,0049 & 0,0106 & 0,0026 & 0,0368 & 0,0224 \\
FROTO & 0,0154 & 0,0155 & 0,0206 & 0,0254 & 0,0158 & 0,0209 & 0,0047 \\
KERVT & 0,0324 & 0,0025 & 0,0091 & 0,0093 & 0,0006 & 0,0205 & 0,0767 \\
OTKAR & 0,0246 & 0,0391 & 0,0308 & 0,0271 & 0,0414 & 0,0175 & 0,0021 \\
Optimal Value & 0,0324 & 0,0391 & 0,0308 & 0,0271 & 0,0414 & 0,0368 & 0,0767 \\
\hline
\end{tabular}

In the last two stages of the method, optimality function values $\left(\mathrm{S}_{\mathrm{i}}\right)$ are calculated for each decision alternative with the help of equation (10). Then, the degree of utility values $\left(\mathrm{K}_{\mathrm{i}}\right)$ is calculated with the help of equation (11), and the final ranking is obtained. The $S_{i}$ and $K_{i}$ values of businesses and the 
findings regarding corporate sustainability performance rankings in terms of economic, environmental, and social dimensions are shown in Table 13.

Table 13. $S_{i}, K_{i}$ Values and Ranking of Alternatives

\begin{tabular}{|c|c|c|c|c|c|c|c|c|c|}
\hline & \multicolumn{3}{|c|}{ Economic Dimension } & \multicolumn{3}{|c|}{ Environmental Dimension } & \multicolumn{3}{|c|}{ Social Dimension } \\
\hline & $S_{i}$ & $\mathbf{K}_{\mathbf{i}}$ & $\begin{array}{l}\text { Rank- } \\
\text { ing }\end{array}$ & $\mathrm{S}_{\mathrm{i}}$ & $K_{i}$ & $\begin{array}{l}\text { Rank- } \\
\text { ing }\end{array}$ & $\mathrm{S}_{\mathrm{i}}$ & $\mathbf{K}_{\mathbf{i}}$ & Ranking \\
\hline AKSA & 0,0893 & 0,3139 & 5 & 0,0231 & 0,0669 & 6 & 0,1250 & 0,4489 & 3 \\
\hline AEFES & 0,0770 & 0,2706 & 6 & 0,1212 & 0,3519 & 3 & 0,0523 & 0,1879 & 6 \\
\hline AYGAZ & 0,0972 & 0,3418 & 4 & 0,2201 & 0,6390 & 1 & 0,0860 & 0,3086 & 5 \\
\hline FROTO & 0,1183 & 0,4161 & 3 & 0,0523 & 0,1517 & 5 & 0,1124 & 0,4034 & 4 \\
\hline KERVT & 0,1512 & 0,5316 & 2 & 0,0603 & 0,1750 & 4 & 0,2081 & 0,7470 & 1 \\
\hline OTKAR & 0,1826 & 0,6422 & 1 & 0,1786 & 0,5184 & 2 & 0,1377 & 0,4945 & 2 \\
\hline Optimal Value & 0,2844 & 1,0000 & & 0,3445 & 1,0000 & & 0,2785 & 1,0000 & \\
\hline
\end{tabular}

According to the information contained in Table 13, based on the results of the corporate sustainability performance ranking made on 6 companies operating in the BIST manufacturing sector, it is seen that the company with the best performance in terms of economic sustainability in 2019 was OTKAR, followed by the companies with stock exchange codes of KERVT and FROTO, respectively. However, it was found that, in the same period, 3 businesses with the lowest performance in terms of economic sustainability were companies coded as AEFES, AKSA, and AYGAZ, respectively.

It is seen that the company that performed best in terms of environmental sustainability in 2019 was AYGAZ, followed by OTKAR, and AEFES, respectively. However, it was found that, in the same period, 3 companies with the lowest performance in terms of environmental sustainability were AKSA, FROTO, and KERVT, respectively.

On the other hand, it is seen that the company, which performed best in terms of social sustainability in 2019, was KERVT, followed by OTKAR and AKSA, respectively. However, it was found that, in the same period, 3 companies with the lowest performance in terms of social sustainability were AKSA, FROTO and KERVT, respectively.

\section{Conclusion and Evaluation}

In this study, the corporate sustainability performances of 6 companies that are listed on the BIST manufacturing sector, that published a sustainability report and which have common criteria, were evaluated using an integrated 
model consisting of CRITIC-ARAS methods. In the study, while weight coefficients for evaluation criteria were determined with the CRITIC method, the financial performance evaluation and success scores of alternatives were determined with the ARAS method.

According to the findings obtained from the CRITIC weighting method, the most important corporate sustainability performance criterion in terms of economic sustainability for BIST production sector companies in 2019 was the rate of increase in the cost of sales. However, it was determined that the criterion which has the least impact on economic sustainability performance is the return on equity ratio. It was seen that, from the viewpoint of environmental sustainability, the non-hazardous waste amount criterion was the criterion with the highest weight, while the greenhouse gas emissions criterion was the criterion with the lowest weight. On the other hand, in terms of social sustainability, the criterion with the highest weight was the criterion of accident frequency rate, while the criterion with the lowest weight was the criterion of the total number of employees.

According to the findings obtained from the ARAS method; when the corporate performance ranking of the businesses included in the scope of analysis was conducted, it was found that among the companies operating in the BIST production sector, the 3 most successful businesses in terms of economic dimension were the companies coded as OTKAR, KERVT, and FROTO. However, in the same period, the 3 most unsuccessful businesses in terms of sustainability were determined as companies coded as AEFES, AKSA, and AYGAZ, respectively. It is seen that the business that performs best in terms of environmental dimension was AYGAZ, followed by OTKAR, and AEFES, respectively. It was found that 3 businesses with the lowest performance in terms of environmental sustainability were AKSA, FROTO and KERVT, respectively. It is seen that, on the other hand, the business that performs best in terms of social dimension was KERVT, followed by OTKAR and AKSA, respectively. Furthermore, it was found that, in the same period, 3 businesses with the lowest performance in terms of social sustainability were AKSA, FROTO and KERVT, respectively.

This study is important since it reveals the issues in which more importance should be attached in order for businesses to increase their sustainability performance. In addition, this study contributed to the literature by 
using the CRITIC-ARAS integrated model for the first time in the measurement of corporate sustainability performance. In the studies to be conducted in this area, the corporate sustainability performance of businesses can be determined and interpreted by using different performance indicators and/or different analysis methods for the same sector or for different sectors.

\section{References}

Aggarwal, P. (2013). Impact of sustainability performance of company on its financial performance: A study of listed Indian companies. Global Journal of Management and Business Research, 13(11), 60-70.

Akbulut, O. Y. (2019). CRITIC ve EDAS yöntemleri ile İş Bankası'nın 2009-2018 yılları arasındaki performansının analizi. Ekonomi Politika ve Finans Araştırmaları Dergisi, 4(2), 249-263.

Akçakanat, Ö., Aksoy, E. and Teker, T. (2018). CRITIC ve MDL temelli EDAS yöntemi ile TR-61 bölgesi bankalarının performans değerlendirmesi. Süleyman Demirel Üniversitesi Sosyal Bilimler Enstitüsü Dergisi, 32, 1-24.

Artiach, T., Lee, D., Nelson, D. and Walker, J. (2010). The determinants of corporate sustainability performance. Accounting and Finance, 50(1), 31-51.

Ayçin, E. (2020). Çok kriterli karar verme: Bilgisayar uygulamalı çözümler. 2. Basım, Ankara: Nobel Akademik Yayıncllik.

Balezentiene, L. and Kusta, A. (2012). Reducing greenhouse gas emissions in grassland ecosystems of the Central Lithuania: Multi-criteria evaluation on a basis of the ARAS method. The Scientific World Journal, 3, 1-11.

Collison, D. J., Cobb, G., Power, D. M. and Stevenson, L. A. (2008). The financial performance of the FTSE4 good indices. Corporate Social Responsibility and Environmental Management, 15(1), 14-28.

Çıtak, L. and Ersoy, E. (2016). Firmaların BIST sürdürülebilirlik endeksine alınmasına yatırımcı tepkisi: Olay çalışması ve ortalama testleri ile bir analiz. International Journal of Alanya Faculty of Business, 8(1), 43-57.

Dahooie, J. H., Zavadskas, E. K., Abolhasani, M., Vanaki, A. and Turskis, Z. (2018). A novel approach for evaluation of projects using an interval-valued fuzzy additive ratio assessment (ARAS) method: A case study of oil and gas well drilling projects. Symmetry, 10(45), 1-32.

Demircioğlu, E. N. and Demet, E. V. E. R. (2019). Sürdürülebilirlik muhasebesinin teorik açıdan incelenmesi. Çukurova Üniversitesi Sosyal Bilimler Enstitüsü Dergisi, 28(3), 59-72. 
Diakoulaki, D., Mavrotas, G. and Papayannakis, L. (1995). Determining objective weights in multiple criteria problems: The CRITIC method. Computers and Operations Research, 22(7), 763-770.

Fettahoğlu, S. (2013). İşletmelerde sosyal sorumluluk ile finansal performans arasındaki ilişki: IMKB'ye yönelik bir uygulama. Sosyal ve Beşeri Bilimler Dergisi, 6(1), 11-20.

Fülöp, G. and Hernádi, B. H. (2013). Sustainability accounting: A success factor in corporate sustainability strategy. New Challenges of Economic and Business Development, 4(1), 229-241.

Gladwin, T., Kennely, J. J. and S.T. Krause (1995). Shifting Paradigms for sustainable development: Implications of management theory and research. Academy of Management Review, 20(4), 874-904.

Kiracı, K. and Bakır, M. (2019). CRITIC temelli EDAS yöntemi ile havayolu işletmelerinde performans ölçümü uygulaması. Pamukkale Üniversitesi Sosyal Bilimler Enstitüsü Dergisi, 35, 157-174.

Koçaslan, G. (2010). Sürdürülebilir kalkınma hedefi çerçevesinde Türkiye'nin rüzgar enerjisi potansiyelinin yeri ve önemi. İstanbul Üniversitesi Sosyal Bilimler Dergisi, 4, 53-61.

Lamberton, G. (2005). Sustainability accounting-a brief history and conceptual framework. Accounting forum, 29(1), 7-26.

Lo, S. F. and Sheu, H. J. (2007). Is corporate sustainability a value-increasing strategy for business?. Corporate Governance An International Review. 15(2), 345-358.

Marti, C. P., Rovira-Val, M. R. and Drescher, L. G. (2015). Are firms that contribute to sustainable development better financially? Corporate Social Responsibility and Environmental Management, 22(5), 305-319.

Önder, Ş. (2017). İşletme karlılı̆ına kurumsal sürdürülebilirliğin etkisi: BIST'te bir uygulama. Muhasebe Bilim Dünyası Dergisi. 19(4), 937-956.

Özdemir, Z. and Pamukçu, F. (2016). Kurumsal sürdürülebilir raporlama sisteminin Borsa İstanbul sürdürülebilirlik endeksi kapsamındaki işletmelerde analizi. Mali Çözüm Dergisi, 26(134), 13-35.

Reddy, K. and Gordon, L. (2010). The effect of sustainability reporting on financial performance: An empirical study using listed companies. Journal of Asia Entrepreneurship and Sustainability, 6(2), 19-42.

Sak, A. F. and Dalgar, H. (2020). Kurumsal sürdürülebilirliğin firmaların finansal performansina etkisi: BIST kurumsal sürdürülebilirlik endeksindeki firmalar üzerine bir araştırma. Muhasebe ve Finansman Dergisi, 85, 173-186. 
Saufi, N. A. A., Daud, S. and Hassan, H. (2016). Green growth and corporate sustainability performance. Procedia Economics and Finance, 35, 374-378.

Schaltegger, S. and Burritt, R. L. (2010). Sustainability accounting for companies: catchphrase or decision support for business leaders? Journal of World Business, 45(4), 375-384.

Searchy, C. and Doaa, E. (2012). Corporate sustainability ratings: An investigation into how corporations use to Dow Jones Sustainability Index. Journal of Cleaner Production, 35(1), 79-92.

Tıraş, H. (2012). Sürdürülebilir kalkınma ve çevre teorik bir inceleme. Kahramanmaraş Sütçü İmam Üniversitesi İ̈BF Dergisi, 2(2), 57-73.

Tokgöz, N. and Once, S. (2009). Şirket sürdürülebilirliği: Geleneksel yönetim anlayışına alternatif. Afyon Kocatepe Üniversitesi İ̈BF Dergisi, 11(1), 249-275.

Tuan, K. (2019). Yönetim kurulu özelliklerinin sürdürülebilirlik raporlarına etkisi: Borsa İstanbul örneği. Pamukkale Üniversitesi Sosyal Bilimler Enstitüsü Dergisi, 36, 233-242.

Tüm, K. (2014). Kurumsal sürdürülebilirlik ve muhasebeye yansımaları. Akademik Yaklaşımlar Dergisi, 5(1), 58-81.

Wiengarten, F., Lo, C. K. and Lam, J. Y. (2017). How does sustainability leadership affect firm performance? The choices associated with appointing a chief officer of corporate social responsibility. Journal of Business Ethics, 140(3), 477493.

Yücel, T. S. (2016). Sürdürülebilirlik ve kurumsal sürdürülebilirlik kavraminin incelenmesi ve muhasebe ile ilişkisi: Teorik bir araştırma. Kesit Akademi Dergisi, 5, 158-181.

Zavadskas, E. K. and Turskis, Z. (2010). A new additive ratio assessment (ARAS) method in multicriteria decision-making. Technological and Economic Development of Economy, 16(2), 159-172.

\section{Citation Information}

Özkan, T. and A $\breve{g}$, A. (2021). Corporate sustainability performance assessment: CRITIC-ARAS integrated model. OPUS-International Journal of Society Studies, 18(42), 5208-5229. DOI: 10.26466/opus.913777. 